\title{
A LINGUAGEM POÉTICA NA NARRATIVA BICHOS DE CONCHAS, DE GLÁUCIO LEMOS
}

Celso Kallarrari (UNEB)'1

Resumo: Pretendemos, neste artigo, apresentar o romance Bichos de Conchas (2008), de Gláucia Lemos, como uma narrativa em prosa cuja linguagem dá margens para perceber nela a poesia. A partir do trabalho cuidadoso feito com as palavras, a autora traz à luz uma linguagem poética; ao mesmo tempo, acessível, simples, mas profunda e, sobretudo, lírica, realista e ficcional, porque o texto literário não pode perder sua aura mágica. Ora é Celeste, a narradora-personagem, quem toma as rédeas da narração, ora é o narrador-onipresente quem busca preencher as lacunas que o texto, quando narrado na primeira pessoa, não consegue, por si só, fazê-lo, de modo que percebemos, na leitura, que há harmonia e desarmonia nas trocas de narração quando se faz alternâncias de narradores entre os 20 capítulos. Ao nosso ver, é na trama da narrativa, conforme nos orienta Benjamin (2012), ou seja, no enredo bem construído, no domínio da palavra, da prosa poética (MOISÉS, 2012), que a autora busca descrever as agruras e os sabores da vida humana. Para tanto, dependerá do leitor, da sua formação, do seu prazer e fruição (BARTHES, 2002), mas também de como esta escrita se apresenta porque, no momento presente, "não é fácil a leitura de livros, não é fácil conseguir leitor de livros” (SANTIAGO, 2014, p. 118), porque “a obra somente é obra quando se converte na intimidade aberta de alguém que a escreveu e de alguém que a leu” (BLANCHOT, 2011). Em Bichos de Conchas, é possível sentir esse alumbramento de palavras, de palavras que querem dizer, que querem expressar-se em emoções como num conjunto inseparável da poetisa, da contista e, nesse momento, da romancista.

Palavras chaves: Bichos de Conchas, narrativa poética, narrador, Gláucia Lemos.

\section{Introdução}

De acordo com Júlio Enrique Correa (2006), pode-se dizer que uma narrativa poética assemelha-se a "uma dança literária das palavras", justamente porque ela, a partir desse jogo concordante de palavras, é atravessada pelo movimento do ritmo e da

\footnotetext{
${ }^{1}$ Doutor em Ciências da Religião. Mestre em Educação. Pós-graduado em Língua Portuguesa. Licenciado em Letras. Graduado em Teologia.E-mail: celsokallarrari@terra.com.br
} 
sonoridade que a cadência enunciativa de uma escrita em prosa poética ${ }^{2}$ se propõe. Maria de Lourdes Dionizio Santos (2001, p. 02) apresenta-nos a definição de narrativa poética de Jean-Yves Tadié quem diz que "é a forma narrativa que capta do poema os seus meios e os seus efeitos, considerando as técnicas pertinentes ao romance e ao poema, simultaneamente”. No romance Bichos de Conchas (2008), de Gláucia Lemos, percebemos, pois, um diálogo narrativo entre os movimentos do ambiente ermo e aquático, da mesmice das coisas, dos acontecimentos e dos não acontecimentos, do dito e não dito (do calar-se), do silêncio das pessoas e do barulho terapêutico das ondas do mar: ela, a narrativa, quem nos evidencia - numa linguagem poética, revezada entre dois narradores, mas, predominantemente, na voz da narradora Celeste, uma dança literária de palavras, semelhante à dança constante das ondas marítimas, no texto em prosa do romance em questão.

\section{Narrativas e o gênero poético}

Walter Benjamin (2012) já havia demonstrado sua preocupação em relação a pessoa do narrador, figura esta vedada ao desaparecimento, tendo em vista a sua própria morte com o surgimento do romance moderno no contexto da modernidade. Isso porque, parafraseando Benjamin (2012, p. 55-56), o romance moderno distancia-se da tradição oral e das especulações da vida e a sua narrativa não leva mais em consideração a "moral da história”, uma vez que o homem moderno perde esta condição e a capacidade de aconselhar. Para Benjamin (2012), somente o romance clássico tem a função primordial de intercambiar experiências. Para ele, o narrador clássico, portanto, é aquele que narra suas experiências de vida, fruto da tradição oral; é aquele que consegue trazer à baila os costumes e conceitos dos antepassados e com eles seus ensinamentos. Influenciado pela barbárie da I Guerra Mundial, chegando a declarar a pobreza cultural e a material do ser humano, Benjamin (2012) declara a morte do narrador clássico, aquele que transmite a sua experiência de boca em boca, uma vez que "as ações da experiência estão em baixa”. Para o autor:

É a experiência de que a arte de narrar está em vias de extinção. São cada vez mais raras as pessoas que sabem narrar devidamente.É cada vez mais frequente que, quando o desejo de ouvir uma história é manifestado, o embaraço se generalize.É como se estivéssemos sendo privados de uma faculdade que nos parecia totalmente segura e inalienável: a faculdade de intercambiar experiências (BENJAMIN, 2012, p. 213)

No que compete a poemas em prosa, alguns poetas, desde o século XVII, a exemplo de Baudelaire, Rimbaud e Mallarmé são os iniciadores desta forma de fazer

\footnotetext{
2 "A poesia identifica-se por ser a expressão do "eu" por meio da linguagem polivalente, ou seja, metafórica, enquanto a prosa se distingue por colocar a tônica na apreensão do "não eu", empregando o mesmo tipo de linguagem" (CORREA, 2006, p. 554).
} 
poesia, explorando, assim, o ritmo musical e harmonioso dos versos. Desse modo, "O poema em prosa luta por alcançar a união entre dois ritmos até então paralelos, quando não antagônicos: o ritmo da poesia e o ritmo da prosa, o amálgama entre as massas sonoro-emotivo-semânticas e as unidades sintáticas” (MOISÉS, 2012,p. 155).

Em tempos hodiernos, apesar de a narrativa poética ser um gênero em discussão muito recente na literatura atual, sabemos, entretanto, que o diálogo entre estes dois gêneros (Prosa e Poesia) literários se instaurou desde tempos longínquos, ou seja, desde os contos populares dos irmãos Grimm, apresentados, à época, como formas naturais e originais da poesia, porque eles falavam numa linguagem e estilo próprios dos dialetos do povo (VALENTI, 2000, p. 699). Nos primórdios do Romantismo, citamos As Confissões, de Rousseau, como uma das grandes influenciadoras do estilo narrativo-poético que dicotomizava o homem em razão-consciência.

É notório o interesse pelo público em relação às obras narrativas em detrimento das obras poéticas. Nas estantes das poucas livrarias que ainda restam neste país, é evidente a publicação de narrativas, sobretudo, de romances e contos em detrimento do gênero poético. Um exemplo disso são as narrativas policiais, fantásticas ou histórias de amor sendo estas preferidas pelo grande público muitas vezes escravizados pela imposição mercadológica. Diante de um contexto cada vez mais totalitário de narrativas em detrimento da poesia, alguns autores - talvez numa tentativa de fuga e/ou de sobrevivência - resolveram apostar em narrativas poéticas.

O gênero poético tem sido pouco publicado pelas grandes editoras do país e, por isso, quase ausentes nas poucas livrarias brasileiras. Em contrapartida, cresce o número de publicação de narrativas, sobretudo de romances em relação aos outros gêneros literários. De fato, publica-se muito mais romances que poesia, e isso é visível. Apesar de existirem vários fatores para explicar a razão para tal fenômeno, um deles é certeiro, qual seja, o mercado literário prefere as narrativas que o texto poético, a exemplo de boa parte dos prêmios literários brasileiros.

Embora saibamos que esta situação não seja, em absoluto, a única razão da ausência da poesia - apesar de muito se escrever neste gênero - não ser tão evidentes nas prateleiras das livrarias, podemos dizer que, no Brasil, alguns autores decidiram por escrever uma literatura cuja narrativa, a prosa-poética, é marcada pelo viés poético. Para tanto, basta lembrarmos de três obras e três autores contemporâneos: Eu Receberia as Piores Notícias dos seus lindos Lábios (2005), de Marçal Aquino, Aos 7 e aos 40 (2013), de José Anzanello Carrascoza, e Sinfonia em Branco (2001), de Adriana Lisboa.

\section{Bichos de Conchas: prosa poética}

Percebemos que alguns escritores-poetas têm navegado pelos textos narrativos e deixado neles pistas do seu ofício, qual seja, o fazer poético. Há, certamente, presente nos textos contemporâneos, uma mistura de elementos narrativos e elementos poéticos que poderíamos chamá-los de "narrativas poéticas”. Talvez 
seja essa uma das possíveis saídas de alguns autores-poetas diante do mercado literário tão excludente em relação à poesia. Talvez não seja esse o motivo, mas a tendência atual de optar por escrever narrativas, uma vez que são mais lidas e/ou preferidas pelo grande público que os poemas. De fato, levaremos um bom tempo ainda para analisar como funciona este mercado, a lei da oferta e procura em relação ao texto poético e o texto em prosa. $O$ fato é que o que, supomos, não acontece com a autora Gláucia Lemos no seu Bichos de Conchas, vencedor do II Prêmio de Literatura UBE/SP e publicado em 2008. Esta autora não migrou simplesmente do texto poético para o texto em prosa e muito menos deixou de escrever nenhum desses gêneros em detrimento de outro, haja vista os inúmeros livros mais variados possíveis escritos em diversos gêneros. O que nos resta dizer que a poetisa Gláucia deixa transparecer, sem muito esforço, na feitura do romance, o lirismo poético já interiorizado na autora, de modo que, ao escrever o texto em prosa, deixa nele, sem grandes intenções, sua marca poética.

Nossa tese é de que o romance Bichos de Conchas se apresenta como uma narrativa cuja linguagem poética é, nela perceptível, a partir de um trabalho cuidadoso da autora no ofício e no manuseio das/com as palavras, oportunizando uma linguagem acessível, simples, mas profunda e, sobretudo, lírica mas realista, porque o texto literário não pode perder sua aura ficcional, sem, todavia, deixar de manter um diálogo com os seus contemporâneos. Ora é Celeste, a narradora-personagem, quem toma as rédeas da narração, ora é o narrador onipresente quem busca preencher as lacunas que o texto, quando narrado na terceira pessoa, não consegue, por si só, fazê-lo, de modo que percebemos, na leitura, harmonia e desarmonia nas trocas de narração quando se faz alternâncias de narradores entre os 20 capítulos do livro.

É, sobretudo, na trama da narrativa, no enredo bem construído, ou seja, no domínio da palavra, da escritura prosaica e poética, que a autora busca descrever as agruras e os sabores da vida humana. As agruras nos machucam, enquanto os sabores nos seduz, porque a narrativa, conforme nos elucida Benjamin (2012), carrega em si as marcas do artesão. Para tanto, dependerá do leitor, da sua formação, do seu prazer e fruição (BARTHES, 2002), mas também de como esta escrita se apresenta porque, no momento presente, "não é fácil a leitura de livros, não é fácil conseguir leitor de livros" (SANTIAGO, 2014, p. 118), porque “a obra somente é obra quando se converte na intimidade aberta de alguém que a escreveu e de alguém que a leu" (BLANCHOT, 2011, p. 29).

A narrativa poética ${ }^{3}$ torna-se, portanto, uma forma de narrar que utiliza-se do tempo e do espaço para falar de si, o que podemos confirmar em As confissões, de Rousseau, quando o narrador-personagem faz um retorno ao passado a partir de uma história romanceada, recriando sua própria vida. Em As confissões, o narrador é, pois, o próprio autor e conta, alongando ou encurtando o tempo, de forma

\footnotetext{
${ }^{3}$ A prosa poética, nesse caso, se caracterizaria pelo aspecto narrativo: a narração é o seu instrumento de eleição. [...] Poderíamos chamá-la por outro termo mais apropriado, qual seja, narrativa poética, cuja narrativa é permeável à poesia. (MOISÉS, 2012, p. 556)
} 
poética, o que quer. De fato, o romance poético é marcado por uma narrativa pessoal, a exemplo do Eu rousseauniano, aproximando, dessa forma, o Romantismo e Narrativa Poética. Esta narrativa privilegia, pois, a natureza com seus cenários e paisagens e determina os acontecimentos e o destino humano.

Nas palavras de Massoud Moisés,

A prosa poética se define, pois, como o texto literário em que se realiza o nexo íntimo entre as duas formas de expressão, a do "eu" e a do "não eu”. Longe de ser pacífico, o encontro é marcado por uma tensão, de que o texto extrai toda a sua força comunicativa. No binômio, o substantivo é representado pela prosa, ou a expressão do "não eu”, ao passo que a poesia funciona como um qualificativo. Estamos, pois, diante de um tipo específico de prosa, assinalado pela fusão da poesia e da prosa. (2012, p. 554)

Em Bichos de Conchas, é possível sentir esse alumbramento de palavras, de palavras que querem dizer, que querem expressar-se em emoções como numa simbiose inseparável da poetisa, da contista e, nesse momento, da romancista.

Em Bichos de Conchas, Gláucia constrói uma narrativa em primeira e terceira pessoa. Divide o livro entre dois narradores. No decorrer das páginas, há traços do lirismo, da poesia presente no desenvolvimento do romance, marcados principalmente por figuras de linguagem. A narrativa gira em torno de Celeste - em alguns momentos, narradora em primeira pessoa - uma menina-moça, sem nome, que vive ao lado do faroleiro Lídio ao qual se sente presa nos seus "silêncios inquietantes”. A mudez de Lídio e suas abstrações ambientam sua situação a ponto de sentir-se numa prisão e nutrir um grande desejo pelo outro lado do mar, ou seja, pelo desconhecido, prefigurado por um paraíso idílico ou de um abismo de trevas. E ela, enquanto narradora, vai construindo uma inquietude humana capaz de fazê-la lançar-se no mundo desconhecido e experimentar um mar hostil e uma praia desconhecida. Mais tarde, sua experiência com a possível liberdade e o desencantamento com o outro lado do mar e com os outros homens a trará de volta ao farol, ao seu verdadeiro homem, Lídio. Essa paisagem humana, cheia de conflitos e incertezas, a narrativa é envolta de um lirismo próprio, marcada pelo estilo de uma autora-poetisa de longa caminhada, não aquele lirismo de um romantismo piegas, mas um lirismo capaz de trazer à sua ficção uma linguagem poética, um universo sonoro, numa cadência lírico-anunciativa.

Devemos alertar que não se trata, sobretudo, de uma prosa poética ao longo de todo o discurso narrativo, mas de uma prosa recheada de versos, ritmos e melodias bem dosados e na medida certa. Trata-se de um texto em prosa cuja ocorrência do lirismo é sentida a partir do uso estratégico das palavras, num compasso quase despercebido, num ritmo suave e envolvente, quase imperceptível. Pode-se ver, na narrativa de Bicho de Conchas, a poética existente através da linguagem suave, perceptíveis aos ouvidos num movimento rítmico contínuo como as ondas do mar, cenário tão bem representado pela poesia presente no texto. Depende, 
entretanto, de que ponto o leitor e/ou ouvinte se encontra. Próximo à praia, em alto mar ou nas alturas, sobre o mar? Às vezes, a proximidade fará com que haja um mergulho profundo dentro do enredo, onde a narrativa - metaforizada aqui por nós, pelas correntezas do mar - é quem dará, certamente, não tão somente a direção, mas, sobretudo, a intensidade da viagem (ou da leitura), do deleite e do sabor de uma leitura espumante.

É esse o tom concordante das palavras trazidas pelos dois narradores, em especial por Celeste, em Bichos de Conchas. Elas têm ritmos, tem sons, versos não rimados mas suavemente organizados no encadeamento das construções e perceptíveis na leitura. Percebemos os sons audíveis das palavras; eles estão ali, inseridos nas mensagens que o bramir das águas provoca ou que o barulho do vento amedronta, nas gaivotas, no singrar dos veleiros que chegam. Estão, sobretudo, no farol exuberante, posto essencial e necessário aos homens donos de diversas navegações. Ele, enquanto estrutura, imóvel; enquanto luz, direciona o homem, se move circularmente. É tangido constantemente pelos ventos, mas permanece em sua quietude eterna, similar a quietude de Lídio. Na voz do narrador em terceira pessoa, notamos alguns questionamentos relacionado ao vento, apresentados em forma de prosopopeia: "O que há mais poderoso que o vento? O que pode ir a toda parte, indomável, como o vento? [...] Quando vinha a noite, porém, e a escuridão tomava o farol, e o mar resmungava forte pelo poder desse mesmo vento que de dia me dava esperança, eu tremia de medo.” (LEMOS, 2008, p. 13)

\section{Cinema e literatura}

Gláucia deixa claro o motivo pelo qual surgiu Bicho de Conchas. Surgiu do contato que ela teve com uma obra cinematográfica $A$ ostra e o vento (1997) que pudemos assistir somente depois de ler a dedicatória na página 5 . Não nos impressiona a inspiração, uma vez que, a priori, foram dos romances, isto é, da literatura, que se projetaram surpreendentes películas cinematográficas.

No mundo contemporâneo, ambas as fontes (Literatura e Cinema) bebem uma da outra. Tendenciosamente é, nesse contexto, que a narrativa contemporânea presente nos filmes nada mais é do que um conjunto de contos, imagens, sons e ritmos que oferecem à linguagem poética infinitas possibilidades de expressão. Se nos filmes, as imagens e os sons são capazes de nos apresentar uma comunicação com alto teor poético, porque os olhos estão propícios a captar - sobretudo a partir da imagem, dos diálogos e, às vezes, da narrativa - a beleza poética do texto, no romance, o conteúdo poético nem sempre é perceptível por uma leitura superficial.

É preciso, antes de tudo, que a sensibilidade do leitor-modelo e o seu mergulhar no mar da leitura, no ato narrativo, aquilo que muitas vezes escapa ao leitor desavisado. A narração é quem conquista o leitor. Se há uma boa narração, e se esta narração é capaz de fazer despertar uma certa cumplicidade, então os ouvidos atentos e imaginação deste leitor serão capazes de fazê-lo, ao seu tempo, descobertas 
surpreendentes e, quiçá, recriar a seu modo o texto lido. Este ato recriador de quem lê, de quem imagina o que lê, não se trata de um simples exercício ou uma mistura interativa de leitor/autor. Ela vai além. Torna-se uma real participação narrativa e imaginativa compartilhada primeiramente com o narrador, consigo mesmo e, depois, com os outros autores de possíveis diálogos sobre o texto lido.

Desse modo, a narração em Bichos de Conchas busca imagens precisas dos sentimentos, do mar, dos seus ritmos e barulhos, das palavras dialogadas em seus dialetos, uma harmonia textual carregada de possibilidades de tantas descobertas, de tantos valores e desvalores dos homens numa língua única e capaz de falar a linguagem humana da alma. É ela, a língua quem narra as proezas e desgraças humanas com a beleza da linguagem, sem, no entanto, impor nenhuma verdade, mas falar a verdade dos sentimentos que só podem ser transmitidos, captados através das palavras.

\section{Imagens, poesia, sons e lirismo}

A narrativa apresenta sonoridades nas palavras, no seu encadeamento, buscando trazer à baila, imagens precisas, sons e sentidos vários. Um recurso estético da autora que se mostra sensível às cores da natureza e da alma humana, permitindo que a criatividade narrativa poética se instaure, numa tentativa perene de buscar atingir a compreensão das coisas.

Bichos de Conchas apresenta não de forma contínua, mais em pinceladas, uma linguagem poética acessível - simples, mas profunda - e, sobretudo, lírica e realista, porque o texto literário não pode perder sua aura ficcional, sem, todavia, deixar de manter um diálogo com os seus contemporâneos. Ficamos envolvidos com o enredo e sentimos a nítida sensação de estar acompanhando, passo a passo, os sonhos, os devaneios e a viagem da personagem principal, Celeste. A literatura exerce esse poder, causa-nos diversas sensações, proporciona-nos alegria, tristeza, dor ou bem-estar. Ela nos provoca e, às vezes, nos conduz às profundezas, aos recônditos obscuros e misteriosos do ser humano. Às vezes, causa-nos admiração, espanto; outras, reação, desconforto, ao ponto de fazermo-nos lembrar da distinção de Roland Barthes (2002) sobre o romance que proporciona o prazer e o romance que proporciona fruição. Para Barthes (2002), o texto de prazer apresenta-se como uma leitura mais clara, porque apresenta-se numa linguagem mais simples, "que contenta, que enche, que dá euforia” (BARTHES, 2002, p. 18).

Bichos de Conchas situa-se entre o prazer e a fruição, porque o texto dá margem para os dois tipos de leitores. Por isso, tudo vai depender, exclusivamente, do leitor. A depender da sua formação, ele poderá se deliciar da história no que diz respeito ao destino, escolhas, lugar paradisíaco, encontro e desencontros dos personagens. Nesse caso, a leitura apresentar-se mais leve, e, por isso, talvez mais prazerosa. Para Santiago (2014, p. 121), numa sociedade do consumo, o livro sofre a crise do "silêncio do leitor" e torna-se cada vez mais obsoleto, porque a literatura, 
ou seja, a grande literatura "não depende do mercado da forma como o cinema ou a televisão dependem” (SANTIAGO, 2014, p. 121).

Entretanto, se o leitor conseguir entender aquilo que ficou nas entrelinhas, no não dito, no desfecho inesperado - intencionalmente "quase" conclusivo -, é porque houve sua cúmplice participação criativa, ou seja, sua intervenção, porque é esta a proposta da autora: que o leitor fique pensando no que leu, conforme evidencia Benjamin em “O Narrador”, ao tecer considerações sobre a obra de Nikolai Leskov: "O extraordinário, o miraculoso é narrado com a maior exatidão, mas o contexto psicológico da ação não é imposto ao leitor. Ele é livre para interpretar a história como quiser, e com isso o episódio narrado atinge uma amplitude que falta à informação” (2012, p. 219). Nesse caso, é possível dizer que o texto é de fruição (e, ao mesmo tempo, de prazer), porque, nele, "toda moedinha lógica está nos interstícios" (BARTHES, 2002, p. 15), na parte final, e a linguagem poética apresenta-se como uma estratégia linguística que o leitor deverá buscar entender, a fim de chegar ao ouro, isto é, à fruição.

Na leitura de Bichos de Conchas, sentimo-nos, deslumbrado, sentimos as ondas baterem nas enseadas, as navegações dos pescadores, o voo majestoso das gaivotas sobrevoando as águas, e o medo do vento quando bramia o mar. Tudo são imagens preciosas de um filme ${ }^{4}$, um belíssimo filme, que nós, embevecidos, não queríamos que chegasse ao final - como uma criança que degusta uma sobremesa, ouvindo a melodia do mar -, embora esperasse, ansiosamente, saber como se daria o desenlace

Em o Bichos de Conchas, há muita coisa ainda não compreendida e não tão perceptível, que o leitor de prazer poderá deixar passar despercebido, principalmente se ignorar os “jogos de linguagem, pois precisará mergulhar nas profundezas do texto. Eis, aqui, apenas um exemplo: Ao iniciarmos a leitura, destacamos dois tipos de narradores. Celeste, a narradora-personagem quem abre a narrativa e divide a narração com outro narrador, um narrador onisciente, ausente da história. Há, intencionalmente, um motivo? Qual? Para o leitor de prazer, isso passaria despercebido. O narrador onipresente busca, por sua vez, preencher as lacunas que o texto - em primeira pessoa - não consegue, por si só, fazê-lo. Ora é Celeste quem toma as rédeas com uma narração poética, em 10 capítulos; ora é o narrador desconhecido nos outros 10 capítulos. Estrategicamente, o capítulo XI é dividido entre os dois narradores. O narrador onisciente inicia a narrativa, e, no meio do capítulo, Celeste é quem toma a fala, é ela quem narra.

\section{Linguagem poética}

No decorrer do romance, as figuras de pensamento (hipérbole, eufemismo, personificação, antítese) são bastante utilizadas. Celeste é dona de uma inquietação,

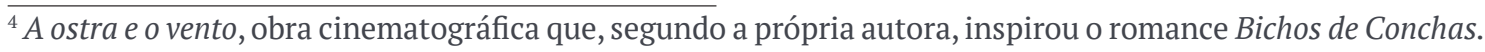


e Lídio, senhor do silêncio, ou seja, ele é o próprio silêncio, ou ainda, um farol silencioso que brilha. Ele busca iluminar, ainda que, foscamente, a vida de Celeste, embora, a princípio, não consegue. Os dois vivem no Farol. Ela, inquieta como as águas do mar. Ele, silencioso, fechado, no seu labirinto de pregoari, como seus búzios, com seus "Bichos de Conchas". Todavia, em Celeste, existe "o desejo de caminhar sem destino, sem compromisso e sem passado. Uma quase certeza de que tudo é possível. De que temos o poder de tecer e desfiar nosso destino" (LEMOS, 2008, p. 15). É ela quem diz isso. Para tanto, a autora utiliza-se - no corpo dos capítulos, cuja narradora é a própria Celeste - de alguns parágrafos em itálico, marcando a voz interior, a voz da consciência, a voz da razão. É uma voz que fala consigo mesma. Vejamos: "Eu só queria fugir do silêncio, conhecer o que havia atrás do horizonte, como as gaivotas que voam nos ventos do farol" (LEMOS, 2008, p. 47). Com efeito, Celeste queria que a maré a levasse, queria ser conduzida pelo vento. Apesar disso, ela tem medo do vento, porque o vento, a natureza, em seu estado bravio, assobiava um assobio amedrontador; preanunciava, pois, um futuro ameaçador. Celeste queria algum lugar bem longe do farol, longe do silêncio, do silêncio de Lídio, porque ela não queria ser prisioneira do silêncio de Lídio. Então, embarca na aventura de ir além, além mar e se lançar nele.

A natureza fala em tons poéticos no romance. É incrível. Que belo sentir isso, numa época em que a natureza sofre as mais diversas agressões humanas, numa época em que ela "geme dores de parto" quando retiram dela as árvores ou quando as queimam! Ela personifica-se, a partir de uma narrativa poética, bela e lírica. Ela, às vezes, parece imortal, mas humana ao mesmo tempo. Com estilo suave e melodioso, a autora humaniza as coisas, humaniza o mar, o vento e as ondas, pois, eles falam, sussurram, resmungam, "fazem barulho como se fossem pessoas, muitas pessoas sussurrando" (LEMOS, 2008, p. 13). O farol, lugar de encontros e desencontros, também ganha vida, pois "o olho vermelho do farol em um compasso regular me beijava de leve, depois se arrastava por cima das ondas, enfeitando, com a volubilidade de sua luz ritmada, a escuridão do barco, do meu corpo em fuga, e dos caminhos do mar" (LEMOS, 2008, p. 20).

Às vezes, a natureza sente raiva, humaniza-se, a partir de predicados humanos: "Um vento raivoso sacudia fortemente galhos e folhagens, e surrava as bandas das janelas", enquanto as ondas rumorejavam "na enchente da lua cheia, de leve” (LEMOS, 2008, p. 37; 43). Outro exemplo: "Daqui a pouco o vento dos teus medos começará a soprar e a assombrar entre os galhos da folhagem, e tu estás sozinha com os fantasmas do vento e com teu filho no ventre". (LEMOS, 2008, p. 72-3)

Até o sol tem ações humanas e arremeda o homem. Olhem a poesia aqui: “O sol continuou a deitar-se todas as tardes nos travesseiros vermelhos do horizonte, até que a noite abafasse as chamas das montanhas com um lençol cinzento que lentamente escurecia, até o costumeiro negrume" (LEMOS, 2008, p. 61). Mais 
adiante: “(...) à espera de que o sol se derramasse na cadeia de montanhas, como calda de cereja, grossa e vermelha, e fosse aos poucos, em frações de segundos, fechando o dossel da penumbra por cima das ondas, e acinzentando o mundo" (LEMOS, 2008, p. 103). E ainda: “(...) olhou o tempo, havia um pouco de sol, mal espremido entre nuvens cinzentas” (LEMOS, 2008, p. 91, grifo nosso)

$\mathrm{O}$ uso de figuras de linguagem torna a vida abstrata, dá-lhe prerrogativas humanas às coisas: "A vida da vila era como que cochilava, já que não adormecia, pois o dia-a-dia permanecia se arrastando” (LEMOS, 2008, 62-63). Até o barco humaniza-se, quando comparado aos estágios da vida: "Singrava, lá adiante, com suas velas desenroladas como ventres grávidos de vento" (LEMOS, 2008, p. 116). E, nesse jogo de palavras, as águas também podem “escolher”, têm livre-arbítrio como nós, seres humanos: "Enfim, a maré não escolhe. Ou é quem escolhe" (LEMOS, 2008, p. 87).

Escreve como quem navega sobre as ondas marítimas dos sentimentos, porque literatura é, sobretudo, sentimento e emoção! Infelizmente, na cultura de massa em que vivemos, os best-sellers, impostos, na sua maioria, pela mídia, não conseguem brincar com as palavras, porque muitos insistem, no jogo dramático, em assassinar as metáforas e as hipérboles, em repetir o mesmo sentido, os mesmos conteúdos. Isso é o que não acontece em Bichos de Conchas, pois o próprio título do livro é uma metáfora da vida dos protagonistas.

O título, Bichos de Conchas, nos instiga, pois, de acordo com Aristóteles, toda arte é imitação; e, de maneira particular, “a imitação é produzida por meio do ritmo, da linguagem e da harmonia, empregados separadamente ou em conjunto” (2001, p. 1). Ora se toda arte é imitação - e aqui a literária -, esta narrativa apresenta-nos momentos dramáticos e trágicos, sem, necessariamente, perder a poesia, a leveza, a magia, cuja pretensão é a imitação da realidade através da linguagem.

Os homens, aqui representados pelas personagens de Celeste e Lídio, são considerados "bichos", ou seja, são comparados às ostras, moluscos frágeis que crescem, protegidos dentro de uma concha calcificada, indicando-nos que tanto uma quanto a outra personagem são motivadas pelas experiências pessoais e pela rudeza que a própria vida as impõe, buscam das formas mais diversas estratégias para se protegerem.

Enquanto ser humano frágil e de comportamento arredio, Lídio, apesar de se manter fechado, protegido, mudo para o mundo e para a própria companheira, aprendeu com a vida que não deve "prender" ninguém como uma concha faz ao proteger a ostra. Celeste busca sair da concha que a envolve, quer viver novas experiências, experimentar a vida, navegar por outras águas e chegar em outras margens onde nunca estivera, pois se sente presa, se sente uma ostra, presa no mundo silencioso de Lídio.

Celeste se defende de Lídio e das outras pessoas, assim como uma ostra faz lançando uma substância (madrepérola) sobre o invasor, petrificando-o. Tanto a personagem-narrador quanto Lídio são identificados pela autora como "bichos 
de conchas", porque vivem presos, livres na natureza, mas protegidos dentro de suas próprias ostras. Para Celeste, que deixou Lídio e fora para a outra margem, somente o tempo foi capaz de amadurecer os seus sentimentos, fazê-la compreender seus temores, desejos, ilusões e a sua realidade. O tempo - assim como acontece com as ostras - propiciaram de, sobremaneira, a Celeste encontrar e cultivar sua pérola dentro de si, descobrindo o outro lado do mundo, encantando-se com o desconhecido, Tadeu, e machucando-se, nele, pôde, afinal, descobrir-se, reencontrar-se consigo mesma.

Em Bichos de Conchas, notemos as comparações, na fala do narrador em terceira pessoa:

Lídio era um sol silencioso e brilhante que refletia uma luzinha na minha inquietação, mas uma luz insuficiente, porque ele tinha o mesmo silêncio do sol. Luz só ilumina, não fala. Por isso é que Lídio era como uma luz, um farol, apesar de imperceptível, na vida de Celeste. Entretanto, não era suficiente, era só o silêncio iluminado (LEMOS, 2008, p. 12).

Lídio era silêncio e mistério. Deixa Celeste livre, não a prende, não usa da violência e nem da força, nem sequer pergunta o que fez longe dele e, muito menos, sobre o possível pai do seu filho, porque para ele "Cada um deve fazer o que tem vontade. Ela foi porque quis, volta se quiser, sem ninguém pedir” (LEMOS, 2008, p. 19). Ao chegar à outra margem, Celeste conhece um casal e é convidada a ficar na casa. Ela tem medo do assobio do vento e, numa noite, em que o vento causava-lhe medo, envolve-se com Tadeu, um pescador, com quem acaba tendo um filho.

Notemos, pois, os aprendizados apreendidos do discurso do narrador em terceira pessoa. Eles nos põem a pensar. São palavras proverbiais. Para Celeste, não podemos fugir do nosso destino, porque:

Quando se abrem os olhos para o mundo pela primeira vez, começa-se a desenrolar um novelo do qual só a morte tem a derradeira ponta. Ninguém pode cortar o fio a meio do caminho, para fazer um recomeço. Tudo o que se tecer no fio do novelo será para sempre. Pode-se fugir. Desfazer, nunca mais. (LEMOS, 2008, p. 26, grifo nosso).

E, ainda, a busca, desenfreadamente, por algo inexplicável, como um curso normal, onde percebemos que todos nós, assim como Celeste que, envolvida por uma linguagem filosófica, buscamos pelo outrem.

Depois do corte que nos aparta, inconformados passamos a vida a buscar, indefinidamente, o inexistente alguém”. Eis a esplêndida conclusão: "Mas ninguém existe. Somos um, entre todos que também são um buscando inexistente alguém (LEMOS, 2008, p. 26, grifo nosso).

Depois que Celeste ficou sozinha e caiu em si, sem o silêncio de Lídio (a princípio, rejeitado por ela), procura, inconscientemente, sua origem, suas raízes, 

seus pensamentos:

\begin{abstract}
Eu não fugi de você. Não, Lídio, eu fugi do seu silêncio. Você não saía de dentro de si mesmo... [...] Não aprendi a entender a frieza das pedras, o silêncio das rochas que existem em você. Até as águas, Lídio, até as águas murmuram ou esbravejam, falam na linguagem sussurrada ou ruidosa, dizem quando estão enchendo, dizem quando estão vazando, e só silenciam quando estão cansadas e dormem. Eu sou inquieta como as águas, Lídio, tenho o tempo de silenciar quando estou cansada e adormeço, mas preciso do sussurro e preciso do ruído quando estou desperta [...] Mas você, Lídio, você é como os búzios fechados, sua vida está encerrada dentro de você, no seu labirinto de pregoari, e não se divide com a inquietação das águas, a minha inquietação líquida e transparente. Muito tempo esperei, mas você tem o silêncio impenetrável das pedras. (LEMOS, 2008, p. 41)
\end{abstract}

Eis a sabedoria popular, apontada por Benjamin (2012) como fadada ao desaparecimento no romance moderno. Ela é uma das marcas da narração em primeira pessoa e mostra-se, aqui, versificada nas palavras de Celeste: "Nenhuma mulher sabe do amor antes de ter um filho. Nenhuma mulher entende o amor senão por esse dom" (LEMOS, 2008, p. 44). Celeste, assim como muitas outras Celestes, só queria “saber o que havia para lá do horizonte” (LEMOS, 2008, p. 80), para lá da sua compreensão. Ela queria descobrir-se, saber quem ela, realmente, era. Buscava suas referências, sua identidade, aquilo que lhe fora ocultado desde o seu nascimento. E, por ironia do destino, a vida prega-lhe peças. O seu passado torna-se presente, presentifica-se no momento em que lhe roubam a sua filha.

No decorrer da leitura, podemos elencar uma grande quantidade de trechos poéticos, elucidados por figuras de linguagem (metáforas, comparação, catacrese, eufemismo, personificação, etc.), por figuras sonoras e harmônicas (aliteração, assonância e onomatopeia) e ainda pelos ritmos e melodias, conforme os exemplos que se seguem:

a) Comparação:

Singrava, lá adiante, com suas velas desenroladas como ventres grávidos de vento (LEMOS, 2008, p. 116)

Meus olhos estavam descobrindo o milagre e foram-se lentamente inundando, como a chuva inundava as pequenas mossas que havia na crosta do rochedo... Entendi que chovera dentro de mim uma chuva de vida, eu estava abençoada. ((LEMOS, 2008, p. 45)

O mar é o caminho para toda parte do mundo. Não tem lugar onde o mar não possa chegar. (LEMOS, 2008, p. 66) 
b) Perífrase:

Tadeu berrou como um louco, e eu senti a terra estremecer. (LEMOS, 2008, p. 61)

c) Personificação:

Há quanto tempo eu não escutava um assobio que não fosse o do vento nas noites escuras que me amedrontavam. (LEMOS, 2008, p. 25)

A lancha aproximava-se roncando leve (LEMOS, 2008, p. 16)

Lá tão distante é que a maré fora jogar o corpo de Simão. Enfim, a maré não escolhe. Ou é quem escolhe. (LEMOS, 2008, p. 87)

d) Metáfora:

Daqui a pouco o vento dos teus medos começará a soprar e a assombrar entre os galhos da folhagem, e tu estás sozinha com os fantasmas do vento e com teu filho no ventre (LEMOS, 2008, p. 72-3)

e) Paradoxo:

Depois do corte que nos aparta, inconformados passamos a vida a buscar, indefinidamente, o inexistente alguém. Mas ninguém existe. Somos um, entre todos que também são um buscando o inexistente alguém (LEMOS, 2008, p. 26)

f) Eufemismo:

Parece que Simão, na ausência de Santa, conseguiu reinventar a tristeza. (LEMOS, 2008, p. 37)

g) Assonância, sonoridade e o lirismo presente na evocação sonora de termos que despertam a emoção estética sem, todavia, prender-se somente na expressividade dos termos e fonemas, mas na adequação verbal às imagens mentais:

Era eu à mercê do sol, da areia, do calor, do enjoo, da gravidez e da culpa. [...] Era eu, só eu. E o universo vazio era tão grande... (LEMOS, 2008, p. 48)

Depois deixei que a maré me levasse ao gosto das águas que arrastam tudo até onde só Deus sabe. (LEMOS, 2008, p. 15)

...olhou o tempo, havia um pouco de sol, mal espremido entre nuvens cinzentas. (LEMOS, 2008, p. 91) 
Como podemos observar, apesar de ser comum existir na prosa de ficção a presença das figuras semânticas, de modo especial a metáfora, na prosa poética, o seu uso é bastante explorado, evidenciando o sentido e o enigma do sentido que sobressai à vista (MOISÉS, 2012, p. 557). Conforme nos instrui Moisés, a prosa literária é permeável ao contágio da poesia, ou seja, "as marcas identificadoras dessa aproximação encontram-se na musicalidade da frase, de modo a haver equivalência, ocasional ou voluntária, entre os membros do período sintático e os hemistíquios métricos", ao passo que "servindo-nos da 'prosa ritmada' podemos construir tanto um conto como um ensaio ou um romance” (2012, p. 554-5)

Bichos de Conchas é, portanto, marcado pelas figuras semânticas, de pensamento, de sintaxe e de som e harmonia. Sua narração é constituída por uma linguagem poética, onde a autora demonstra o domínio da palavra, da escrita, uma vez que, entre os inúmeros livros já publicados, ela se apresenta como hábil prosadora e poetisa, observadora, porque a sua descrição, a sua linguagem, é revestida de pele, de carne humana. Ela nos fere, nos machuca, mas também nos seduz, nos encanta, nos enche de poesia.

\section{Linguagem filosófica}

O desfecho da narrativa torna-se surpreendente. Essa é outra estratégia da autora. Ela não nos dá todas as cartas, mas nos convida, enquanto leitores, a participar da sua escrita, a pensar o final, desfazê-lo, imaginar, a nosso bel prazer, outras possibilidades que o desfecho sugere. Ele não está predefinido, caberá a nós, coparticipes, dar a resolução final. Isso é cumplicidade, interatividade com o leitor. Aqui, no discurso direto, vemos a revelação do aprendizado. Celeste confessa a Lídio a aprendizagem filosófica de suas andanças, de sua viagem, de sua busca:

- Vim lhe dizer que não consegui virar gaivota, nem viajar pelo vento. Que já encontrei o que está do outro lado do horizonte, na outra margem do mar, e é tudo igual, um lado e o outro. E que conheci o muito que são os meus sonhos e o pouco que eu sou (LEMOS, 2008, p. 100).

Em resposta às suas próprias indagações, a voz da sua consciência declara: "Não são as asas o que dá a liberdade, Celeste, o que dá a liberdade é a vida do coração. Não é o vento o que leva para longe, o que leva para longe é o sonho. (LEMOS, 2008, p. 101, grifo nosso)

É ela, Celeste, quem fala, num tom conclusivo e reflexivo, consigo mesma.

Pressupomos que Gláucia Lemos tenha nascido nas proximidades do mar, e, próximo a ele, tenha vivido, porque ao falar, profundamente, sobre o mar, demonstra certa intimidade com suas águas salgadas, com seus ventos que assobiam e amedrontam com suas ondas traiçoeiras. Por outro lado, percebemos, pois, que as águas, tanto salgadas quanto doces, são temáticas fortes nos seus escritos. Afinal, 
são 36 livros durante sua vida literária. Pudemos presenciar isso no livro de contos Todas as Águas (LEMOS, 2015). Neste livro, a temática das águas se repete. Nele, também há ondas, rios, águas da chuva e “águas dos olhos”, porque, conforme nos salienta Gerana Damulakis, "As narrativas tomam a água - as águas - não para compor cenários, mas para participar das vidas e das mortes que são contadas” (LEMOS, 2015, p. 12, prefácio). Agora, se a autora não nasceu ou viveu a sua infância às margens do mar, e se eu acreditasse em reencarnação, diria que, em vidas passadas, provavelmente ela tenha alçado ou hasteado velas, lançado redes ao mar, e recolhidas cheias de peixes de variadas espécies. Talvez ela mesma tenha sido a capitã, segurando firme o leme do Princesa, do Fé em Deus ou até mesmo do Flor Amarela ${ }^{5}$ que singram o mar como quem singra o papel e deixa, nele, suas palavras encantadas de sonho com gosto de vida, capazes de registrar - numa leveza invejável - as mentes e os sentimentos, a essência humana.

Para Celeste, a outra margem, além do Farol, demonstrava ser, aparentemente, a felicidade. Foi preciso, porém, que ela conhecesse a outra margem, a outra felicidade, conhecesse Tadeu, a quem ela se entregou e com que ela teve um filho, conhecesse o pai, Bartô, quem estava tão próximo (mas tão distante), e só pôde encontrá-lo do outro lado do mar, conhecesse a mãe, quem Celeste sequer sabia da sua existência. Conhecer para se autoconhecer, para se valorizar, para perceber que a verdadeira felicidade está ali, no que parece contraditório, no Farol, no silêncio agonizante de Lídio. Com efeito, depois que o filho é roubado, e a história de Celeste repete-se na história da filha, a outra margem passa ser, novamente, $\mathrm{o}$ local de desejo, porque, nela, reside a felicidade.

\section{Conclusão}

A nosso ver, trata-se, pois, de um livro com uma narrativa marcada por uma linguagem poética, porque, ao nos aprofundar no oceano misterioso que é a literatura de Gláucia Lemos, mergulhamos num mar profundo - nesta "obra de notável qualidade", ímpar, original, escrita numa "linguagem vívida e plena de continuados impactos emocionais inesperados” (PCJ, 2004) -, compreenderemos um pouco mais do ser humano. De fato, o romance Bichos de Conchas situa-se como uma prosa recheada de poemas, de melodias, de um lirismo poético que consegue exprimir a vida humana, "lírica e realista, pulsante, numa linguagem vívida e plena de continuados impactos emocionais inesperados", ou seja, "uma obra de notável qualidade. Original no tema e no tratamento", conforme se expressou o parecer da comissão julgadora do II Concurso Literário UBE/SP.

Apesar de sua narrativa estar dividida entre dois narradores, é a voz de Celeste, personagem-narrador, a voz do eu-lírico que - ao contar a sua história em primeira pessoa - apresenta-se como um narrador clássico, capaz de atrair a atenção do

\footnotetext{
${ }_{5}^{5}$ Princesa, Fé em Deus e Flor Amarela são os nomes dos veleiros que aparecem no romance.
} 
leitor ao narrar suas experiências de vida, como fizeram muitos de nossos antepassados, recorrendo a tradição oral, quando nos contavam suas histórias e com elas seus ensinamentos. Cabe lembrar que, contrariando a morte do narrador clássico anunciada por Benjamin (2012), a narradora de Bichos de Conchas consegue, à luz da sabedoria popular, passar "a experiência de boca em boca" cuja "fonte recorreram todos os narradores" (p. 214).

No romance, os traços de uma linguagem poética são elementos-chave que a escritora, enquanto poetisa, soube refinar nas palavras prosaicas como uma "dança literária" de ritmos e melodias, levando em consideração a "moral da história", porque, conforme nos instrui Walter Benjamin (2012), o narrador clássico exerce ainda a condição e a capacidade de contar história, e de aconselhar, com doses necessárias de poesia, numa linguagem próxima da oralidade do linguajar do povo, transmitindo ao leitor suas mais diversas experiências.

\title{
THE POETIC LANGUAGE PRESENT IN THE NARRATIVE"BICHOS DE CONCHAS", BY GLÁUCIA LEMOS
}

\begin{abstract}
In this article, we intend to present the novel Bichos de Conchas, by Gláucia Lemos, as a prose narrative whose language allows us to perceive poetry in it. From the careful work done with the words, the author brings to light a poetic language; at the same time, accessible, simple, but profound and, above all, lyrical, realistic and fictional, because the literary text cannot lose its magical aura. Sometimes it is Celeste, the narrator-character, who takes the reins of the narration, sometimes it is the omnipresent narrator who seeks to fill in the gaps that the text when narrated in the first person cannot, by itself, do so, so we realize, in reading, that there is harmony and disharmony in the exchanges of narration when the narrators alternate among the 20 chapters. In our view, it is in the plot of the narrative, as guided by Benjamim (2012), that is, in the well-constructed plot, in the domain of the word, of poetic prose (MOISÉS, 2012), which the author seeks to describe the hardships and flavors of human life. Therefore, it will depend on the reader, on their training, on their pleasure and enjoyment (BARHTES, 2002), but also on how this writing presents itself because, at the present time, "it is not easy to read books, it is not easy to get a reader of books" (SANTIAGO, 2014, p. 118), because "the work is only a work when it becomes the open intimacy of someone who wrote it and someone who read it" (BLANCHOT, 2011). In Bichos de Conchas, it is possible to feel this illumination of words, of words that want to say, that want to express themselves in emotions as an inseparable set of the poetess, the short story writer and, at that moment, the novelist.
\end{abstract}

Keywords: Bichos de Conchas, poetic narrative, narrator, Gláucia Lemos. 


\section{Referências:}

ARISTÓTELES. Arte poética. In. Domínio público: biblioteca digital desenvolvida em software livre. Disponível em: http://www.dominiopublico.gov.br/ download/texto/cv000005.pdf . Acesso em 12 de junho de 2021.

BARTHES, Roland. O prazer do texto. São Paulo: Perspectiva, 2002.

BENJAMIN, Walter. O narrador: considerações sobre a obra de Nikolai Leskov. In. Magia e técnica, arte e política: ensaios sobre literatura e história da cultura. $8^{\mathrm{a}} \mathrm{Ed}$. Revista. Trad. Sérgio Paulo Rouanet. São Paulo: Brasiliense, 2012, p. 213-239.

BENJAMIN, Walter. Experiência e Pobreza. Trad. Sérgio Paulo Rouanet. In. Magia e técnica, arte e política. Ensaios sobre literatura e história da cultura. $8^{\text {a }}$ Ed. Revista. Trad. Sérgio Paulo Rouanet. São Paulo: Brasiliense, 2012, p. 123-128

BENJAMIN, Walter. A crise do romance. Trad. Sérgio Paulo Rouanet. In. Magia e técnica, arte e política. Ensaios sobre literatura e história da cultura. $8^{\mathrm{a}} \mathrm{Ed}$. Revista. Trad. Sérgio Paulo Rouanet. São Paulo: Brasiliense, 2012, p. 55-62

BLANCHOT, Maurice. O espaço literário. Rio de Janeiro: Rocco, 2011.

DAMULAKIS, Gerana. In. LEMOS, Gláucia. Todas as águas. Prefácio. Simões Filho: Kalango, 2015.

CORREA, Julio Enrique. A narrativa poética: a recriação e interação pela concordância. In. Revista ACB, v. 11, n. 2, 2006. Disponível em: <https://revista. acbsc.org.br/racb/article/view/482/617> Acesso em 20 de outubro de 2020.

COSTA, Aramis Ribeiro. In. LEMOS, Gláucia. Todas as águas. Orelha. Simões Filho: Kalango, 2015.

KALLARRARI, Celso. Entre o prazer e fruição: Bichos de Conchas, de Gláucia Lemos. In. SANTOS, Valci V., BOGO, Maria Nalva R. de Araújo, KALLARRARI, Celso (Orgs). Educação e desenvolvimento: Língua, Literatura e Formação. v. 3 São Paulo: Pontes, 2017, p. 307-16.

LEMOS, Gláucia. Bichos de Conchas. São Paulo: Scortecci, 2007.

LEMOS, Gláucia. Todas as águas. Kalango: Simões Filho, 2015.

LIMA, Rocha. Gramática Normativa da Língua Portuguesa. $37^{\mathrm{a}}$ ed. Rio de Janeiro: José Olympio, 1999.

MOISÉS, Massaud. A criação literária: poesia e prosa.

Ed. Revista e atualizada. São Paulo: Cultrix, 2012.

PARECER DA COMISSÃO JULGADORA DO II CONCURSO LITERÁRIO UBE/ SCORTECCI. In. Contra-capa. LEMOS, Gláucia. Bichos de Conchas. São Paulo: Scortecci, 2007. 
ROUSSEAU, Jean-Jacques. As confissões. Rio de Janeiro: Ediouro, 1965.

SANTIAGO, Silviano. O cosmopolitismo do pobre. Belo Horizonte: Editora UFMG, 2004.

VALENTI, Eduardo. Todos los cuentos de los Hermanos Grimm [Prólogo]. $1^{\text {a }}$ Edição. Madrid/ Buenos Aires: Editoriales Rudolf Steiner, S.L., 2000.

SANTOS, Maria de Lourdes Dionizio. A narrativa poética de Rousseau: um breve olhar sobre o Eu em As confissões. In. Revista Unicamp, 2001. Disponível em: <https://www.unicamp.br/ jmarques/cursos/2001rousseau/ mlds.htm\#: :text=A\%20narrativa\%20po\%C3\%A9tica\%20\%2D\%20de\%20 acordo,romance\%20e\%20ao\%20poema\%2C\%20simultaneamente> Acesso em 20 de outubro de 2020.

Recebido em 20 de abril de 2021

Aprovado em 11 de maio de 2021 